\title{
Loktanella spp. Gb03 as an algicidal bacterium, isolated from the culture of Dinoflagellate Gambierdiscus belizeanus
}

\author{
Anmar Hameed Bloh ${ }^{1}$, Gires Usup² and Asmat Ahmad ${ }^{1}$ \\ 1. School of Bioscience and Biotechnology, Faculty of Science and Technology, University Kebangsaan Malaysia, \\ 43600 Bangi, Selangor, Malaysia; 2. School of Environmental and Natural Resources Sciences, Faculty of Science and \\ Technology, University Kebangsaan Malaysia, 43600 Bangi, Selangor, Malaysia. \\ Corresponding author: Asmat Ahmad, e-mail: asmat@ukm.edu.my, \\ AHB: anmarhameed@yahoo.com, GU: gires@ukm.my \\ Received: 01-10-2015, Revised: 23-12-2015, Accepted: 29-12-2015, Published online: 12-02-2016
}

doi: 10.14202/vetworld.2016.142-146 How to cite this article: Bloh AH, Usup G, Ahmad A (2016) Loktanella spp. Gb03 as an algicidal bacterium, isolated from the culture of Dinoflagellate Gambierdiscus belizeanus, Veterinary World 9(2): 142-146.

\begin{abstract}
Aim: Bacteria associated with harmful algal blooms can play a crucial role in regulating algal blooms in the environment. This study aimed at isolating and identifying algicidal bacteria in Dinoflagellate culture and to determine the optimum growth requirement of the algicidal bacteria, Loktanella sp. Gb-03.

Materials and Methods: The Dinoflagellate culture used in this study was supplied by Professor Gires Usup's Laboratory, School of Environmental and Natural Resources Sciences, Faculty of Science and Technology, University Kebangsaan Malaysia, Malaysia. The culture was used for the isolation of Loktanella sp., using biochemical tests, API 20 ONE kits. The fatty acid content of the isolates and the algicidal activity were further evaluated, and the phenotype was determined through the phylogenetic tree.

Results: Gram-negative, non-motile, non-spore-forming, short rod-shaped, aerobic bacteria (Gb01, Gb02, Gb03, Gb04, $\mathrm{Gb} 05$, and Gb06) were isolated from the Dinoflagellate culture. The colonies were pink in color, convex with a smooth surface and entire edge. The optimum growth temperature for the Loktanella sp. $\mathrm{Gb} 03$ isolate was determined to be $30^{\circ} \mathrm{C}$, in $1 \%$ of $\mathrm{NaCl}$ and $\mathrm{pH}$. Phylogenetic analysis based on $16 \mathrm{~S}$ rRNA gene sequences showed that the bacterium belonged to the genus Loktanella of the class Alphaproteobacteria and formed a tight cluster with the type strain of Loktanella pyoseonensis ( $97.0 \%$ sequence similarity).

Conclusion: On the basis of phenotypic, phylogenetic data and genetic distinctiveness, strain Gb-03, were placed in the genus Loktanella as the type strain of species. Moreover, it has algicidal activity against seven toxic Dinoflagellate. The algicidal property of the isolated Loktanella is vital, especially where biological control is needed to mitigate algal bloom or targeted Dinoflagellates.
\end{abstract}

Keywords: algicidal activity, Gambierdiscus belizeanus, Loktanella sp. Gb-03, optimization growth.

\section{Introduction}

The widespread of poisonous cyanobacterial blooms in rivers, lakes and reservoirs globally has become an increasing health problem. These blooms are also responsible for livestock death and concurrently posing great public health challenge, in addition, to their havoc on the aquatic ecosystems [1-3]. Several bacteria isolated in association with various harmful algal bloom (HAB) species, including dinoflagellates and raphidophytes, have been shown to have algicidal activity [4-8]. Bacteria associated with HABs can play an important role in regulating algal blooms in the environment [9-11]. Laboratory studies had evaluated bacteria or bacteria-derived algicidal compounds to develop a short-term solution for controlling HABs growth [12-17]. These studies showed

Copyright: Bloh, et al. Open Access. This article is distributed under the terms of the Creative Commons Attribution 4.0 International License (http://creativecommons.org/licenses/by/4.0/), which permits unrestricted use, distribution, and reproduction in any medium, provided you give appropriate credit to the original author(s) and the source, provide a link to the Creative Commons license, and indicate if changes were made. The Creative Commons Public Domain Dedication waiver (http://creativecommons.org/ publicdomain/zero/1.0/) applies to the data made available in this article, unless otherwise stated. that algicidal bacteria can exhibit a range of specificity and may use mechanisms to mediate algicidal effects on targeted Dinoflagellate species. Many studies have found algicidal bacteria which have activity on a specific genus or species of Dinoflagellate [18-20] while others studies showed algicidal bacteria has activity against range of algal classes [21-23].

On the other hand, bacteria with algicidal activities such as those from the genus Loktanella has been described [24], to originally contained three species, namely Loktanella salsilacus, Loktanella fryxellensis, and Loktanella vestfoldensis. Subsequently, six other species from this genus were described, these includes Loktanella hongkongensis [25,26], Loktanella agnita and Loktanella rosea [27], Loktanella koreensis [28], Loktanella maricola [29] and Loktanella atrilutea [30] were described.

To the best of our knowledge, there is no study investigating marine algicidal bacteria against toxic Dinoflagellates in Malaysia water. We hypothesized that bacteria isolates from Malaysian water possess strong and powerful algicidal activity against wide range of Dinoflagellates species. Attempts to isolate algicidal bacteria from Malaysian water could reveal 
the potentials of Malaysian marine as a good source of natural algicides, and they may be of great importance in term of $\mathrm{HAB}$ control.

Hence, this study aimed at isolating marine algicidal bacteria from Dinoflagellates culture and to optimize their growth requirement. Here we report the taxonomic characterization of a Loktanella-like bacterial, Gb-03, which was isolated from Dinoflagellate culture.

\section{Materials and Methods \\ Ethical approval}

There is no need of ethical approval for such type of study.

\section{Source of Dinoflagellate culture}

The Dinoflagellate culture used in the study contain Dinoflagellate species such as Coolia malaynesis, Alxandrium sp., Alxandrium leei, Alxandrium affine, Alxandrium tamiyavanichi, Alxandrium tamarense, Gambierdiscus belizeanus, and Ostreopsis. The culture was kindly supplied by Professor Gires Usup, School of Environmental and Natural Resources Sciences, Faculty of Science and Technology, University Kebangsaan Malaysia, 43600 (UKM) Bangi, Malaysia. The culture was continuously cultivated in ES-DK medium [31].

\section{Isolation}

Dinoflagellate culture from samples in UKM marine laborator were used for the isolation, and the algicidal activity of the most consistent isolate of the six isolates was further investigated. For isolation, standard dilution plating technique at $25^{\circ} \mathrm{C}$ on marine agar 2216 (MA;Difco) was used. The resultant suspension was serially diluted in 10-fold steps by the addition of $1 \mathrm{ml}$ of the previous dilution to $9 \mathrm{ml}$ saline, $0.1 \mathrm{ml}$ aliquots from each diluted suspension were spread on MA 2216 (Difco) plates. The plates were then incubated under aerobic conditions at $25^{\circ} \mathrm{C}$ for 5 days. The morphological, physiological and biochemical characteristics of isolates were investigated using routine cultivation on MA at $30^{\circ} \mathrm{C}$ for $36-48 \mathrm{~h}$. Isolates were maintained on MA at $4^{\circ} \mathrm{C}$ for short-term preservation and as a glycerol suspension $(20 \%, \mathrm{w} / \mathrm{v}$ in distilled water) at $-80^{\circ} \mathrm{C}$ for long-term preservation.

\section{Characterization}

Growth at various $\mathrm{NaCl}$ concentrations was investigated using nutrient broth (NB) 2216 (NB; Difco). Growth at various temperatures $\left(4-45^{\circ} \mathrm{C}\right)$ was measured on MB. Growth on NB (Difco), trypticase soy broth (TSB; Difco), MacConkey broth (Difco) and URE broth base were tested.

Colony morphology and pigmentation were determined using a culture grown at $30^{\circ} \mathrm{C}$ for $36-48 \mathrm{~h}$. Cell morphology was observed under light microscopy (E600; Nikon). Motility was assessed on a semi-solid agar tube containing marine broth (Difco) supplemented with $0.4 \%$ agar. Cells were inoculated by stabbing with a straight needle and the tube was incubated at $25^{\circ} \mathrm{C}$ for 5 days. Gram-staining was performed using a Gram-stain methods. Growth under anaerobic conditions was determined after incubation in a forma anaerobic chamber on MA plate for $48 \mathrm{~h}$ at $30^{\circ} \mathrm{C}$. Growth in the absence of $\mathrm{NaCl}$ was investigated using NB (Difco). Oxidase and catalase activities were determined according to Ledeboer and Doern [32]. Other physiological and biochemical properties were tested using API 20NE (bioMérieux, Marcy l'Etoile, France). For these tests, cells were suspended in a solution of $0.85 \%$ of $\mathrm{NaCl}$. Results were recorded after $48 \mathrm{~h}$ incubation at $30^{\circ} \mathrm{C}$.

\section{Genetic identification}

DNA extraction

Sterivex filters were thawed, and DNA was extracted following a modification of the method of Weon et al. and Maarit Niemi et al. [29,33]. Filters were filled with $1.8 \mathrm{ml}$ sodium chloride-tris-ethylenediamine-tetraacetic acid (EDTA) buffer $(10 \mathrm{mM}$ tris-hydrochloride [pH 8.0], $1 \mathrm{mM}$ EDTA, $10 \mathrm{mM}$ $\mathrm{NaCl})$ containing fresh lysozyme $(5 \mathrm{mg} / \mathrm{mL})$ and sealed with a syringe and cap for a $1 \mathrm{~h}$ incubation at $37^{\circ} \mathrm{C}$. A $3 \mu 1$ aliquot of proteinase $\mathrm{K}(20 \mathrm{mg} / \mathrm{mL})$ and $100 \mu 1$ of $10 \%$ sodium dodecyl sulfate solution were added to the filter and incubated for $2 \mathrm{~h}$ at $60^{\circ} \mathrm{C}$. Then $100 \mu 1$ of $\mathrm{NaCl}(5 \mathrm{M})$ was added to the tube, and $80 \mu \mathrm{l}$ of cethyletrimethylammonium bromide was added and incubated for $10 \mathrm{~min}$ at $65^{\circ} \mathrm{C}$. After that $600 \mu \mathrm{l}$ of chloroform: isoamyle alcohol (24:1) was added to the tube and centrifuged at $1500 \times \mathrm{g}$ for $5 \mathrm{~min}$ at $4^{\circ} \mathrm{C}$. The clear part was transferred to a clean tube and equal volume of phenol: chloroform:isoamyle alcohol (25:24:1) was added to the tube.

The sample was centrifuged at $10,000 \times g$ for $5 \mathrm{~min}$, and the supernatant was transferred to a clean tube. The DNA was precipitated by the addition of $300 \mu 170 \%$ ethanol. By centrifugation at $14,500 \times g$ for $30 \mathrm{~min}$, and the precipitated DNA was collected. After discarding the supernatant, the DNA was re-suspended in $400 \mu \mathrm{l}$ tris-EDTA buffer and incubated at $37^{\circ} \mathrm{C}$ for $1 \mathrm{~h}$.

\section{Polymerase chain reaction (PCR)}

The 16S rRNA was amplified using universal bacterial primers $27 \mathrm{~F}$ and $1492 \mathrm{R}$, according to Neefs et al., 1990. PCR amplification was performed with 30 thermal cycles programmed as follows; denaturation for $1 \mathrm{~min}$ at $94^{\circ} \mathrm{C}$, annealing for $2 \mathrm{~min}, 30 \mathrm{~s}$ at $55^{\circ} \mathrm{C}$, an extension for $2 \mathrm{~min}, 30 \mathrm{~s}$ at $72^{\circ} \mathrm{C}$, and with a final elongation step of $5 \mathrm{~min}$ at $72^{\circ} \mathrm{C}$. The molecular size of PCR amplicon was determined by agarose electrophoresis. The PCR products (amplicon) were purified using Q1Aprep Spin Miniprep Kits prior to sequencing [34].

The 16S rRNA sequences were aligned using CLUSTAL W software Ver. 1.7 [35]. Kimura's two-parameter model [36] was applied for the calculations of evolutionary distance. A phylogenetic tree 
was constructed using the neighbor-joining method in MEGA 6 software [37]. Gb 03 sequences were deposited in NCBI GenBank with the accession numbers; Loktanella sp. strain UKMGb03A (KU199217), Loktanella sp. strain UKMGb03B (KU199218) and Loktanella sp. strain UKMGb03C (KU199219).

Fatty acid extraction was carried out by method described by Desbois and Smith [38]. The cellular fatty acid profiles of strain $\mathrm{Gb}-03$ consisted of straight-chain saturated and unsaturated components with small amounts of hydroxyl.

Fatty acids; these profiles were almost similar to those of other members of the genus Loktanella $[24,26,27,29,30]$. The fatty acid profiles of strain Gb-03 is shown in Table-1.

\section{Algicidal activity}

In this experiment, Alxandrium sp., A. leei, A. affine, A. tamiyavanichi, A. tamarense, G. belizeanus, and Ostreopsis were used to investigate the algicidal activity of the isolates. We used test flask, $10 \mathrm{ml}$ of the Dinoflagellates culture at the mid-exponential growth phase $\left(1.0 \times 10^{3} 135 \mathrm{cell} / \mathrm{mL}\right)$ was added in the test flask, and $1 \mathrm{ml}$ of the isolate culture was added to the test flask as well, to test the algicidal activity of Gb03 culture on Dinoflagellate. After $24 \mathrm{~h}$ incubation time the cells were observed using counting chamber (Sedgwick-Rafter cells [grid]).

\section{Results and Discussion}

\section{Description of Loktanella sp. Gb-03}

The cells were Gram-negative, aerobic and rodshaped (0.6-0.86, 1.3-3.0 mm), non-motile. Colonies were circular, smooth, convex with an entire margin and pinkish in color. The isolates were observed to grow between 10 and $45^{\circ} \mathrm{C}$ and the optimum growth temperature was observed to be $30^{\circ} \mathrm{C}$. The isolates were also found to grow in a range of $\mathrm{pH}$ between $\mathrm{pH} 6.0-12.0$ and the optimum $\mathrm{pH}$ was found to be $\mathrm{pH}$ 7.0-8.0. The isolate grows on nutrient agar supplemented with $0.5-1.0 \%(\mathrm{w} / \mathrm{v}) \mathrm{NaCl}$, with optimum growth at $1 \%$. While the isolates were able to grow in the presence of nutrient agar supplemented with $\mathrm{NaCl}$, the bacteria were observed to be unable to grow in nutrient agar with no $\mathrm{NaCl}$ supplementation. The isolate was positive for catalase and oxidase activities, nitrate reduction, and gelatin liquefaction. But it was negative for glucose fermentation, arginine dihydrolase and indole production (API 20NE) (Table-2). The isolate does not grow in MacConkey broth and URE broth, but it grows in TSB (Difco) $[24,27,29,30]$.

Following the amplification of the bacteria DNA with PCR, using 16S rRNA gene, the $1300 \mathrm{bp}$ amplified DNA was sequenced, and the sequence of the $16 \mathrm{~S}$ rRNA of Gb-03 strain was aligned in GenBank database with related available sequences. The nearest identity was those of Loktanella sp. (99\%). Relationship between Gb-03 and genus Loktanella was very close (Figure-1) this is shown in the phylogenetic tree based on 16S rRNA sequence. Based on the biochemical analysis and phylogenetic tree, the isolate was identified as Loktanella sp.

\section{Emended description of the genus Loktanella}

The cells are Gram-negative, strictly aerobic, moderately halotolerant, chemoheterotrophic, nonspore-forming and rod-shaped. Motility was observed to be variable among species and when observed, the cells were motile by means of flagella. The cells were cytochrome oxidase and catalase is positive. Colony colors were variable (white, pink, whitish pink, beige or light orange) depending on the species. The optimal temperature for growth was $25^{\circ} \mathrm{C}$. The dominant fatty acid found on the isolate was $\mathrm{C} 18$ : $1 \mathrm{v} 7 \mathrm{c}$ while $\mathrm{Q}-10$ was the major ubiquinone. The polar lipids were diphosphatidyl glycerol, phosphatidyl choline, and phosphatidyl glycerol. DNA G+C contents were 59.1-67.5 mol\%. Phylogenetically, the genus belongs to the Rhodobacter group within the class Alphaproteobacteria. The species was identified to be L. salsilacus based on the ememded description of the genus [24]. Since it has been established that there are algicidal bacteria that

Table-1: Cellular fatty acid content of strain Gb03.

\begin{tabular}{lc}
\hline Fatty acid & Gb03 \\
\hline Saturated & \\
C $_{16: 0}$ & 3.2 \\
C $_{18\llcorner 0}$ & 4.2 \\
Unsaturated & \\
C $_{16}$ & 4.7 \\
$C_{18}$ & 3.8 \\
$C_{20}$ & 6.1 \\
Hydroxy & \\
$C_{10}$ & 0.7 \\
$C_{15}$ & 0.7 \\
\hline
\end{tabular}

Table-2: Biochemical test on the isolates using API 20NE.

\begin{tabular}{|c|c|c|c|c|c|c|}
\hline $\begin{array}{l}\text { Colonies } \\
\text { pigment }\end{array}$ & Pink-beige & $\begin{array}{c}\text { Light } \\
\text { orange }\end{array}$ & Pink & Pink & $\begin{array}{c}\text { Light } \\
\text { orange }\end{array}$ & Pink \\
\hline \multicolumn{7}{|l|}{ API 20NE } \\
\hline No3 & + & - & + & + & - & + \\
\hline TRP & + & - & - & + & - & - \\
\hline GLU & + & - & - & - & - & - \\
\hline $\mathrm{ADH}$ & - & - & - & - & - & - \\
\hline URE & - & - & - & - & - & - \\
\hline ESC & - & + & + & + & - & + \\
\hline GEL & + & + & + & + & + & + \\
\hline PNG & + & + & + & - & + & + \\
\hline GLU & + & + & + & - & + & + \\
\hline ARA & + & + & + & - & + & + \\
\hline MNE & + & + & + & - & + & + \\
\hline MAN & + & + & + & + & + & + \\
\hline NAG & - & - & - & + & - & + \\
\hline MAL & + & - & + & + & - & - \\
\hline GNT & - & - & + & + & - & - \\
\hline CAP & + & - & - & - & - & - \\
\hline ADI & + & - & - & - & - & - \\
\hline MLT & - & - & + & - & + & + \\
\hline CIT & - & - & - & - & - & - \\
\hline PAC & - & - & - & - & - & - \\
\hline
\end{tabular}

$+=$ Positive, $-=$ Negative, API=Analytical profile index 


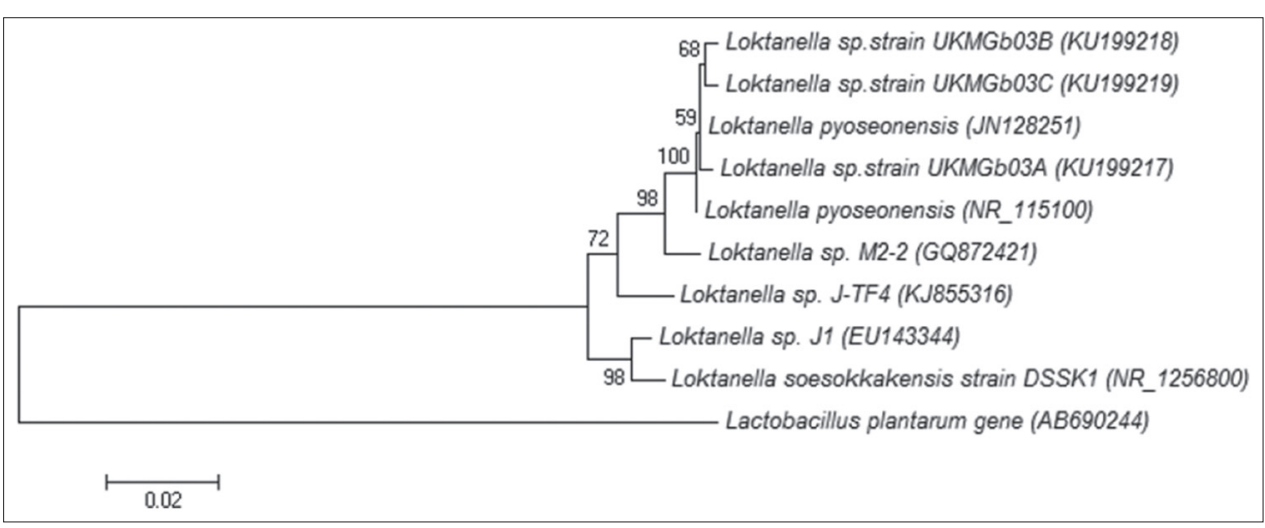

Figure-1: Phylogenetic three.

Table-3: Algicidal activity of isolates against some Dinoflagellate using NB as control.

\begin{tabular}{|c|c|c|c|c|c|c|c|}
\hline Isolates & A. tropicale & A. leei & A. affine & A. tamiyovon-ichi & A. tamarense & G. belizeanus & Ostreopsis \\
\hline Gb-01 & 50 & 40 & 50 & 40 & 50 & 50 & 50 \\
\hline Gb-02 & 40 & 40 & 30 & 40 & 40 & 50 & 40 \\
\hline Gb-03 & 70 & 50 & 95 & 70 & 90 & 90 & 60 \\
\hline Gb-04 & 30 & 30 & 30 & 50 & 70 & 70 & 50 \\
\hline Gb-05 & 70 & 30 & 40 & 50 & 60 & 70 & 50 \\
\hline Gb-06 & 80 & 60 & 50 & 50 & 40 & 50 & 40 \\
\hline
\end{tabular}

A. tropicale=Alexandrium tropicale, A. tamarense=Alexandrium tamarense, A. leei=Alxandrium leei,

A. affine=Alxandrium affine, A. tamiyovon-ichi=Alexandrium tamiyovon-ichi, G. belizeanus=Gambierdiscus belizeanus, $\mathrm{NB}=$ Nutrient broth

kill algae and that these algicidal bacteria can be used as biological control agents [38], the isolation of an algicidal bacterium with proven algicidal activity from Dinoflagellate culture is a significant finding.

\section{Algicidal activity}

Each of the six isolate (Gb-01, Gb-02, Gb-03, Gb-04, Gb-05 and Gb-06) showed the different percentage of algicidal activity on the different species of Dinoflagellates been tested in this study (Table-3). Among the six isolates, Loktanella sp. Gb-03 was observed to have the highest algicidal activity against a range of the tested bacteria following $24 \mathrm{~h}$ incubation, with the highest algicidal activity seen against $A$. affine, where the algicidal activity was observed to be as high as 95. In view of the fact that the effect of algicidal bacteria on microbial communities have been demonstrated to be clearly hazardous [38], the findings of this study could be of great value, especially when biotic control of HABs becomes necessary.

\section{Conclusion}

The isolated marine bacteria in this study showed a powerful algicidal activity against wide range of Dinoflagellates species, indicating the potential of Malaysian marine as a good source of natural algicides, especially in the biotic control of HABs. This appears to be the first study to isolate and investigate marine algicidal bacteria and to investigate their algicidal effect against toxic Dinoflagellates in Malaysian water. The isolate retained algicidal stability at the optimum growth conditions, suggesting that the isolate is capable of being stable especially during the manufacturing process and in the applied area.

\section{Authors' Contributions}

AHB and AA designed the experiment and conducted the experimental work. AHB, GU, and AA were involved in scientific discussion and analysis of the data. GU and AA drafted and revised the manuscript. All authors read and approved the final manuscript.

\section{Acknowledgments}

This work was supported by grants 04-01-SF14 and UKM GUP BTK 07-75-198. The research grant from MOSTI, the Malaysian Government body was provided to first author through the University: Universiti Kebangsaan Malaysia,43000 Bangi, Selangor, Malaysia.

\section{Competing Interests}

The authors declare that they have no competing interests.

\section{References}

1. Chorus, I., Falconer, I.R., Salas, H.J. and Bartram, J. (2000) Health risks caused by freshwater cyanobacteria in recreational waters. J. Toxicol. Environ. Health Part B Crit. Rev., 3(4): 323-347.

2. Guo, Z., Zhang, H., Liu, S. and Lin, S. (2013) Biology of the marine heterotrophic Dinoflagellate Oxyrrhis marina: Current status and future directions. Microorganisms, 1(1): 33-57.

3. Chen, T., Liu, Y., Song, S., Li, C., Tang, Y.Z. and Yu, Z. (2015) The effects of major environmental factors and nutrient limitation on growth and encystment of planktonic Dinoflagellate Akashiwo sanguinea. Harmful Algae, 46: 62.

4. Yoshinaga, I., Kawai, T., Takeuchi, T. and Ishida, Y. (1995) Distribution and fluctuation of bacteria inhibiting the growth of a marine red tide phytoplankton Gymnodinium mikimotoiin Tanabe Bay (Wakayama Pref., Japan). Fish. Sci., 61: 780-786.

5. Tian, C., Liu, X., Tan, J., Lin, S., Li, D. and Yang, H. (2012) 
Isolation, identification and characterization of an algicidal bacterium from Lake Taihu and preliminary studies on its algicidal compounds. J Environ. Sci., 24(10): 1823-1831.

6. Paerl, H.W., Xu, H., McCarthy, M.J., Zhu, G.W., Qin, B., Li, Y.P. and Gardner, W.S. (2011) Controlling harmful cyanobacterial blooms in a hyper-eutrophic lake (Lake Taihu, China): The need for a dual nutrient (N \& P) management strategy. Water Res., 45(5): 1973-1983.

7. Ni, L., Acharya, K., Hao, X. and Li, S. (2012) Isolation and identification of an anti-algal compound from Artemisia annua and mechanisms of inhibitory effect on algae. Chemosphere., 88(9): 1051-1057.

8. Cai, W., Wang, H., Tian, Y., Chen, F. and Zheng, T. (2011) Influence of a bacteriophage on the population dynamics of toxic Dinoflagellates by lysis of algicidal bacteria. Appl. Environ. Microbiol., 77(21): 7837-7840.

9. Orlofske, S.A., Jadin, R.C., Hoverman, J.T. and Johnson, P.T. (2014) Predation and disease: Understanding the effects of predators at several trophic levels on pathogen transmission. Freshwat Biol., 59: 1064-1075.

10. Anderson, D.M., Cembella, A.D. and Hallegraeff, G.M. (2012) Progress in understanding harmful algal blooms: Paradigm shifts and new technologies for research, monitoring, and management. Annu. Rev. Mar. Sci., 4: 143-176.

11. Richards, F.A., Huntsman, S.A., Brink, K.H., Barber, R.T. and Blasco, D. (2013) The Role of Circulation and Stability in Controlling the Relative Abundance of Dinoflagellates and Diatoms Over the Peru Shelf. American Geophysical Union, Washington, DC.

12. Lovejoy, C., Bowman, J.P. and Hallegraeff, G.M. (1998) Algicidal effects of a novel Pseudoalteromonas isolate (class Proteobacteria, gamma subdivision) on harmful algal bloom species of the genera Chattonella, Gymnodinium, and Heterosigma. Appl. Environ. Microbiol., 64: 2806-2813.

13. Skerratt, J.H., Bowman, J.P., Hallegraeff, G.M., James, S. and Nichols, P.D. (2002) Algicidal bacteria associated with blooms of a toxic dinoflagellate in a temperate Australian estuary. Mar. Ecol. Prog. Ser., 244: 1-15.

14. Hare, C.E., Demir, E.D., Coyne, K.J., Cary, S.C., Kirchmen, D.L. and Hutchins, D. (2005) A bacterium that inhibits the growth of Pfiesteria piscicida and other dinoflagellates. Harmful Algae, 4(2): 221-234.

15. Roth, P.B., Twiner, M.J., Wang, Z., Dechraoui, M.Y.B. and Doucette, G.J. (2007) Fate and distribution of breve toxin $(\mathrm{PbTx})$ following lysis of Karenia brevis by algicidal bacteria, including analysis of open A-ring derivatives. Toxicon., 50(8): 1175-1191

16. Roth, P.B., Mikulski, C.M. and Doucette, G.J. (2008b) Influence of microbial interactions on the susceptibility of Karenia spp. To algicidal bacteria. Aquat. Microb. Ecol., 50: 251-259.

17. Kim, M., Jeong, S. and Lee, S. (2008) Isolation, identification, and algicidal activity of marine bacteria against Cochlodinium polykrikoides. J. Appl. Phycol. 20(6): 1069-1078.

18. Fu, L.J., An, X.L., Dong, L., Zhou, L.J., Tian, Y. and Zheng, T.L. (2011) Isolation and alga-inhibiting characterization of Vibrio sp. BS02 against Alexandrium tamarense. World J. Microbiol. Biotechnol., 27: 2949-2956.

19. Wang, B.X., Zhou, Y.Y., Bai, S.J., Su, J.Q., Tian, Y., Zheng, T.L. and Yang, X.R. (2010) A novel marine bacterium algicidal to the toxic Dinoflagellate Alexandrium tamarense. Lett. Appl. Microbiol., 51: 552-557.

20. Wang, B.X., Yang, X.R., Lu, J.L., Zhou, Y.Y., Su, J.Q., Tian, Y., Zhang, J., Wang, G.Z. and Zheng, T.L. (2012) A marine bacterium producing protein with algicidal activity against Alexandrium tamarense. Harmful Algae, 13: 83-88.

21. Wang, M.H., Peng, P., Liu, Y.M., Jia, R.B. and Li, L. (2013) Algicidal activity of a dibenzofuran-degrader Rhodococcus sp. J. Microbiol. Biotechnol., 23(2): 260-266.
22. Zhang, H., Yu, Z.L., Huang, Q., Xiao, X., Wang, X., Zhang, F.Y., Wang, X.Q., Liu, Y.D. and Hu, C.X. (2011) Isolation, identification and characterization of phytoplankton-lytic bacterium CH-22 against Microcystis aeruginosa. Limnologica, 41: 70-77.

23. Ji, Y.C. (2012) Algicidal activity of marine Alteromonas sp. KNS-16 and isolation of active compounds. Biosci. Biotechnol. Biochem., 76(8): 1452-1458.

24. Van Trappen, S., Mergaert, J. and Swings, J. (2004) Loktanella salsilacus gen. nov., sp. nov., Loktanella fryxellensis sp. nov. and Loktanella vestfoldensis sp. nov., new members of the Rhodobacter group, isolated from microbial mats in Antarctic lakes. Int. J. Syst. Evol. Microbiol., 54: 1263-1269

25. Yoon, J.H., Kang, S.J., Lee, S.Y. and Oh, T.K. (2007) Loktanella maricolasp. nov., isolated from sea water of the East Seain Korea. Int. J. Syst. Evol. Microbiol., 57: $1799-1802$

26. Lee, S.D. (2012) Loktanella tamlensis sp. nov., isolated from seawater. Int. J. Syst. Evol. Microbiol., 62: 586-590.

27. Ivanova, E.P., Zhukova, N.V., Lysenko, A.M., Gorshkova, N.M., Sergeev, A.F., Mikhailov, V.V. and Bowman, J.P. (2005) Loktanella agnita sp. nov. and Loktanell arosea sp. nov., from the North-West Pacific Ocean. Int. J. Syst. Evol. Microbiol., 55: 2203-2207.

28. Tsubouchi, T., Shimane, Y., Mori, Y., Miyazaki, M., Tame, A. and Uematsu, K. (2013) Loktanella cinnabarina sp. nov., isolated from a deep subseafloor sediment, and emended description of the genus Loktanella. Int. J. Syst. Evol. Microbiol., 63: 1390-1395.

29. Weon, H.Y., Kim, B.Y., Yoo, S.H., Kim, J.S., Kwon, S.W., Go, S.J. and Stackebrandt, E. (2006) Loktanella koreensis sp. nov., isolated from sea sand in Korea. Int. J. Syst. Evol. Microbiol., 56: 2199-2202.

30. Yoon, J.H., Jung, Y.T. and Lee, J.S. (2013) Loktanella litorea sp. nov., isolated from seawater. Int. J. Syst. Evol. Microbiol., 63: 175-180.

31. Kokinos, J.P. and Anderson, D.M. (1995) Morphological development of resting cysts in cultures of the marine Dinoflagellate Lingulodinium polyedrum (= L. machaerophorum). Palynology, 19: 143-166.

32. Ledeboer, N.A. and Doern, G.V. (2011) Haemophilus. In: Versalovic, J., Carroll, K.C., Funke, G., Jorgensen, J.H., Landry, M.L., Warnock, D.W., editors. Manual of Clinical Microbiology. $10^{\text {th }}$ ed. American Society for Microbiology (ASM Press), Washington, DC. p588-602.

33. Maarit Niemi, R., Heiskanena, I., Walleniusa, K. and Lindströmb, K. (2001) Extraction and purification of DNA in rhizosphere soil samples for PCR-DGGE analysis of bacterial consortia. J. Microbiol. Methods, 25(3): 155-165.

34. Kodani, S., Imoto, A., Mitsutani, A. and Murakami, M. (2002) Isolation and identification of the antialgal compound, harmane (1-methyl-2-carboline), produced by the algicidal bacterium, Pseudomonas sp. K44-1. J. Appl. Phys., 14: 109-114.

35. Thompson, J.D., Gibson, T.J., Plewniak, F., Jeanmougin, F. and Higgins, D.G. (1997) The CLUSTAL_X windows interface: Flexible strategies for multiple sequence alignment aided by quality analysis tools. Nuc. Acids Res. 25: 4876-4882.

36. Kimura, M. (1980) A simple method for estimating evolutionary rates of base substitutions through comparative studies of nucleotide sequences. J. Mol. Evol., 16: 111-120.

37. Saitou, N. and Nei, M. (1987) The neighbor-joining method: A new method for reconstructing phylogenetic trees. Mol. Biol. Evol., 4: 406-425.

38. Desbois, A.P. and Smith, V.J. (2010) Antibacterial free fatty acids: Activities, mechanisms of action and biotechnological potential. Appl. Microbiol. Biotechnol., 85(6): 1629-1942. 